\title{
KARAKTERISTIK PASIEN THALASEMIA MAYOR DI BLUD RSU CUT MEUTIA ACEH UTARA TAHUN 2018
}

\author{
Harvina Sawitri ${ }^{1}$, Cut Asmaul Husna ${ }^{2}$ \\ ${ }^{1}$ Bagian Ilmu Kesehatan Masyarakat, Fakultas Kedokteran, Universitas Malikussaleh \\ ${ }^{2}$ Bagian Mikrobiologi, Fakultas Kedokteran, Universitas Malikussaleh \\ Corresponding Author : harvina.sawitri@unimal.ac.id
}

\begin{abstract}
Abstrak
Talasemia mayor sebagai penyakit genetik yang diderita seumur hidup akan membawa banyak masalah bagi penderitanya. Mulai dari kelainan darah berupa anemia kronik akibat proses hemolisis, sampai kelainan berbagai organ tubuh baik sebagai akibat penyakitnya sendiri ataupun akibat pengobatan yang diberikan. Sampai saat ini, transfusi darah masih merupakan penatalaksanaan utama untuk menanggulangi anemia pada talasemia mayor. Jenis penelitian ini adalah penelitian dengan menggunakan desain cross sectional pada 50 responden di Badan Layanan Umum Rumah sakit Cut Meutia dengan teknik convenient sampling untuk mengetahui karakteristik pasien thalasemia yang menjalani transfusi darah. Hasil penelitian menunjukkan pasien dengan jenis kelamin lakilaki lebih banyak dibandingkan dengan pasien dengan jenis kelamin perempuan, rata-rata usia 9,82 tahun ( $\mathrm{SD} \pm 3,44)$, rata-rata berat badan adalah 23,64 $\mathrm{Kg}(\mathrm{SD} \pm 8,26)$, rata-rata kadar hemoglobin adalah $6,15 \mathrm{mg} / \mathrm{dL}(\mathrm{SD} \pm 1,32)$ dan rata-rata kebutuhan darah adalah $299,5 \mathrm{ml}(\mathrm{SD} \pm 98)$.
\end{abstract}

Kata kunci: thalasemia mayor, karakteristik, kebutuhan darah

\section{CHARACTERISTICS OF THALASEMIA MAJOR PATIENTS AT RSUD CUT MEUTIA NORTH ACEH BLUD 2018}

\begin{abstract}
Thalassemia major as a genetic disease suffered for life will bring many problems for the sufferer. Starting from a blood disorder in the form of chronic anemia due to the process of hemolysis, to various body organs abnormalities either as a result of the disease itself or due to the treatment given. Until now, blood transfusion is still the threatment to overcome anemia in thalassemia major. This research using cross sectional design on 50 respondents at BLUD RSU Cut Meutia Hospital with convenient sampling technique to determine the characteristics of thalassemia patients who undergoing blood transfusion. The results showed that from sex variable, mainly is male patients, an average of age is 9.82 years $(\mathrm{SD} \pm 3.44)$, the average body weight was $23.64 \mathrm{Kg}(\mathrm{SD} \pm 8,26)$, the average hemoglobin level was $6.15 \mathrm{mg} / \mathrm{dL}(\mathrm{SD} \pm 1.32)$ and the average blood requirement was $299.5 \mathrm{ml}(\mathrm{SD} \pm 98)$.
\end{abstract}

Keywords: thalassemia major, characteristics, blood needs 


\section{PENDAHULUAN}

Thalasemia adalah gangguan sintesis hemoglobin akibat penurunan produksi satu atau lebih rantai globin dan merupakan penyakit herediter yang diturunkan secara autosomal resesif (1). Thalassemia mayor masih merupakan masalah di bidang hematologi oleh karena tingginya angka kejadian serta berbagai akibat yang ditimbulkan oleh penyakit ini. Gen pembawa sifat thalassemia mayor di negara-negara mediterania seperti Italia, Yunani, Malta, Sardinia, dan Cyprus berkisar antara 10-16\%. Sedangkan di Asia seperti China, Malaysia dan Indonesia berkisar antaar 3-10\% (2). Pada populasi dunia, diperkirakan 3\% (150 juta orang) pembawa gen $\beta$ talasemia (3). Di Indonesia, angka pembawa talasemia- $\beta$ adalah 3\%-5\%, bahkan di daerah tertentu mencapai $10 \%$. Berdasarkan hasil penelitian, dengan perhitungan dari angka kelahiran dan jumlah penduduk di Indonesia diperkirakan pasien talasemia yang baru lahir cukup tinggi, mencapai 2500 bayi pertahun. Jumlah pasien yang terdaftar di Pusat Talasemia, Departemen Ilmu Kesehatan Anak, FKUI-RSCM, sampai dengan bulan Agustus 2009 mencapai 1.494 pasien dengan rentang usia terbanyak antara 11-14 tahun. Jumlah pasien baru terus meningkat setiap tahunnya mencapai 100 orang/tahun. (4).

Sampai saat ini talasemia belum dapat disembuhkan. Pengobatan yang utama adalah transfusi darah yang dilakukan setiap bulan seumur hidupnya. Biaya suportif yang dikeluarkan seperti, transfusi dan terapi kelasi bisa mencapai 200-300 juta/anak/tahun, belum termasuk biaya jika terjadi komplikasi (4). Pemberian tranfusi darah secara terus-menerus akan menyebabkan terjadinya penumpukan besi pada jaringan parenkim hati dan disertai dengan kadar serum besi yang tinggi. Efek samping dari tranfusi adalah meningkatnya akumulasi zat besi dalam tubuh (5). Penelitian yang dilakukan Anggororini, Fadlyana, dan Idjradinata (2009) yang dilakukan pada anak usia 10-18 tahun di RSUP Dr. Hasan Sadikin Bandung ditemukan sebanyak 25 (83\%) anak kelompok dengan thalasemia mengalami keterlambatan pertumbuhan dan kematangan seksual. Penyebab masalah ini adalah adanya perbedaan pemberian kelasi besi sehingga jumlah besi di dalam tubuh akan berbeda- beda(6).

Hasil penelitian sebelumnya menyatakan penderita talasemia mulai transfusi ratarata berusia 3,78 tahun, dan frekuensi transfusi sebagian besar 1 bulan 1 kali (87,5\%). Salah satu penatalaksanaannya yaitu menyediakan jumlah kebutuhan darah oleh pihak penyedia darah untuk transfusi agar kebutuhan darah penderita talasemia dapat 
tercukupi setiap kali melakukan transfusi sehingga penderita talasemia dapat mempertahankan hidupnya dengan baik (7)

\section{METODE}

Jenis penelitian ini adalah penelitian dengan menggunakan desain cross sectional, dimana variabel terukurnya diamati pada satu waktu. Penelitian akan dilakukan di Rumah Sakit Umum Cut Meutia Kabupaten Aceh Utara. Populasi dalam penelitian ini adalah seluruh pasien talasemia mayor yang melakukan transfusi di Rumah Sakit Umum Cut Meutia Kabupaten Aceh Utara. Sampel penelitian ini adalah seluruh pasien talasemia mayor yang melakukan transfusi di Rumah Sakit Umum Cut Meutia Kabupaten Aceh Utara dan memenuhi kriteria inklusi dan kriteria ekslusi. Kriteria inklusi adalah penderita melakukan tranfusi darah secara rutin minimal satu bulan sekali selama tahun 2018. Kriteria adalah eksklusi tidak tersedia data yang lengkap dari variabel yang akan diteliti. Besar sampel menggunakan metode total sampling yang berjumlah 50 orang pasien thalasemia mayor. Penelitian ini menggunakan metode convenient sampling. Variabel dalam penelitian ini adalah jenis kelamin, usia, berat badan, kadar hemoglobin dan kebutuhan darah

\section{HASIL PENELITIAN}

Karakteristik pasien thalasemia mayor berdasarkan kebutuhan darah, jenis kelamin, usia, berat badan dan kadar hemoglobin dapat dilihat pada tabel dibawah ini

Tabel 1. Karakteristik pasien thalasemia berdasarkan jenis kelamin

\begin{tabular}{lcc}
\multicolumn{1}{c}{ Variabel } & N & Persen (\%) \\
\hline \multicolumn{1}{c}{ Jenis Kelamin } & & \\
Laki-laki & 27 & 54 \\
Perempuan & 23 & 46 \\
Total & 50 & 100
\end{tabular}

Berdasarkan tabel diatas, pasien dengan jenis kelamin laki-laki lebih banyak (54\%) dibandingkan dengan pasien dengan jenis kelamin perempuan (46\%). 
Tabel 2. Karakteristik pasien thalasemia berdasarkan usia, berat badan dan kadar hemoglobin

\begin{tabular}{lrrrrr}
\hline Variabel & \multicolumn{1}{l}{ Satuan } & \multicolumn{1}{c}{ Min } & \multicolumn{1}{c}{ Max } & \multicolumn{1}{c}{ Rata-rata } & \multicolumn{1}{l}{ SD } \\
\hline Usia & Tahun & 4 & 18 & 9,82 & 3,44 \\
Berat badan & $\mathrm{Kg}$ & 13 & 50 & 23,64 & 8,26 \\
Kadar & $\mathrm{mg} / \mathrm{dL}$ & 3,4 & 9,8 & 6,15 & 1,32 \\
Hemoglobin & & & & & \\
Kebutuhan & $\mathrm{ml}$ & 125 & 525 & 299,50 & 98,00 \\
Darah & & & & & \\
\hline
\end{tabular}

Berdasarkan tabel diatas rata-rata usia 9,82 tahun $(\mathrm{SD} \pm 3,44)$, rata-rata berat badan adalah 23,64 $\mathrm{Kg}(\mathrm{SD} \pm 8,26)$, rata-rata kadar hemoglobin adalah 6,15 mg/dL $(\mathrm{SD} \pm 1,32)$ dan rata-rata kebutuhan darah adalah 299,5 $\mathrm{ml}(\mathrm{SD} \pm 98)$

\section{PEMBAHASAN}

Hasil penelitian karakteristik pasien thalassemia berdasarkan jenis kelamin menunjukkan pasien dengan jenis kelamin laki-laki lebih banyak (54\%). Penelitian ini sejalan dengan hasil penelitian di RSUP H. Adam Malik tahun 2006-2008 tentang karakteristik penderita thalassemia yang dirawat dengan jenis kelamin terbanyak adalah laki-laki (63,3\%) (9). Hasil ini juga sesuai dengan penelitian Jelvehgari M (2004) di kota Tabriz, Iran yang melaporkan bahwa penderita thalassemia terbanyak adalah laki-laki $(65 \%)(8)$

Karakteristik pasien berdasarkan usia menunjukkan rerata usia pasien adalah 9,82 tahun. Hasil ini sesuai dengan penelitian di RSUP H. Adam Malik tahun 2006-2008 yang menyatakan bahwa usia terbanyak ada pada usia 6-15 tahun (65,8\%) (9). Penderita thalassemia paling banyak ditemukan pada usia tersebut disebabkan penderita umumnya baru datang berobat pada usia 4-6 tahun karena klinis yang semakin pucat, walaupun manifestasi klinis sudah bisa diperiksa saat pasien berusia 1-2 tahun. Anak-anak dengan Thalasemia mayor tampak normal saat lahir, tetapi akan mengalami anemia pada usia 318 bulan. Pada Thalasemia mayor yang gejala klinisnya jelas, gejala tersebut telah terlihat sejak anak berusia dibawah 1 tahun. Sedangkan pada Thalasemia minor yang gejalanya ringan, biasanya datang berobat pada usia 4-6 tahun (10). Usia sangat berpengaruh pada kebutuhan darah transfusi pada penderita talasemia. Setiap kenaikan usia 1 tahun, maka 
kebutuhan darah akan bertambah sekitar 0,816 mililiter. Makin bertambah usia, frekuensi transfusi darah yang diterima setiap bulan juga meningkat karena makin bertambah usia,kondisi penyakit makin memburuk sehingga kebutuhan transfusi darah makin meningkat. Kebutuhan darah yang diperlukan pada setiap tranfusi berikutnya berangsur meningkat. Jumlah darah yang diberikan setiap tranfusi meningkat denganpeningkatan usia dan dengan pertumbuhan anak. Jika penderita mempunyai limpa yang besar yang penghancuran darah terlalu cepat, mereka membutuhkan darah lebihbanyak, tetapi jika limpa sudah diangkat, kebutuhan darah mereka sedikit berkurang (11). Sebagian besar pasien yang berusia 0-5 tahun menerima transfusi darah satu kali setiap bulan sedangkan pasien yang berusia 11-20 sebagian besar menerima transfusi darah dua kali dalam sebulan. Pada penderita talasemia mayor program transfusi darah secara teratur akan menjamin pertumbuhan dan perkembangan di masa anak-anak. Penderita talasemia pada anak yang berusia 3-4 tahun hanya membutuhkan 1unit kantong darah, tetapi seiiring dengan peningkatan usia sekitar 10 tahun, kebutuhan darah meningkat menjadi dua unit kantong darah, bersamaan dengan pertumbuhan dan perkembangan anak. Hal yang penting dalam perawatan anak talasemia adalah menjaga level $\mathrm{Hb}$ rata-rata tetap sama (14).

Rerata berat badan pasien pada penelitian ini didapatkan 23,64 kg. Berat badan termasuk variabel yang penting dalam menghitung kebutuhan darah pada setiap pasien yang akan melakukan transfusi. Hasil ini sesuai dengan penelitian Rejeki, dkk (2014) yang menyatakan Setiap kenaikan 1 kilogram berat badan, kebutuhan darah bertambah 13,4 mililiter. Berat badan termasuk variabel yang penting dalam menghitung kebutuhan darah pada setiap pasien yang akan melakukan transfusi (7). Dari waktu ke waktu, kebutuhan darah pada pasien yang lain juga dapat berbeda tergantung berat badan, apabila saat melakukan transfusi darah berat badan mengalami kenaikan dari waktu melakukan transfusi darah sebelumnya, kebutuhan darah saat itu cenderung mengalami kenaikan. Hasil ini juga sejalan dengan penelitian Zaki N (2012) di RSU Adam Malik yang menunjukkan hasil kadar Hb pada kunjungan awal adalah 5-10 g/dL (63.3\%) (8). Kadar $\mathrm{Hb}$ sebelum tranfusi dijadikan dasar petugas untuk menentukan kebutuhan darah. Apabila kadar $\mathrm{Hb}$ mengalami penurunan $1 \mathrm{~g} / \mathrm{dL}$, kebutuhan darah akan bertambah sebesar 81 mililiter. Hemoglobin adalah suatu zat di dalam sel darah merah yang berfungsimengangkut zat asam dari paru-paru ke seluruh tubuh, juga memberi warna merah pada eritrosit. Hemoglobin manusia terdiri dari persenyawaan hem dan globin. Hemterdiri dari zat besi $(\mathrm{Fe})$ dan globin adalah suatu protein yang terdiri dari rantai 
polipeptida. Hemoglobin pada manusia normal terdiri dari 2 rantai alfa dan 2 rantai beta. Penderita Thalasemia tidak mampu memproduksi salah satu dari protein tersebut dalam jumlah yang cukup, sehingga sel darah merahnya tidak terbentuk dengan sempurna. Akibatnya hemoglobin tidak dapat mengangkut oksigen dalam jumlah yang cukup. Oleh karena itu, penderita Thalasemia mengalami anemia sepanjang hidupnya (12). Thalasemia terjadi akibat kelainan atau perubahan gen globin $\alpha$ atau $\beta$ yang mengatur produksi rantai $\alpha$ atau $\beta$. Thalasemia terjadi jika rantai globin berkurang atau tidak terbentuk sama sekali. Keadaan ini menyebabkan produksi hemoglobin terganggu dan umur eritrosit memendek. Dalam keadaan normal, umur eritrosit berkisar 120 hari. Gejala yang timbul akibat dari thalasemia seperti anemia, pembesaran limpa, dan Fascies Cooley's (sumsum memproduksi sel darah merah berlebihan sehingga rongga sumsum membesar menyebabkan penipisan tulang dan penonjolan pada dahi) (13)

Kebutuhan darah pada satu pasien dengan pasien lain berbeda tergantung kadar $\mathrm{Hb}$ pra transfusi yang diperiksa saat akan menjalani transfusi darah (Rejeki, dkk, 2014). Hasil rerata kebutuhan darah pada penelitian ini adalah 299,5 ml. Dosis yang digunakan untuk transfusi PRC pada anak adalah 10-15 mL/kgBB/hari apabila $\mathrm{Hb}>6,0 \mathrm{~g} / \mathrm{dL}$, sedangkan pada $\mathrm{Hb}<5,0 \mathrm{gr} / \mathrm{dl}$ transfusi dapat dilakukan $5 \mathrm{ml} / \mathrm{kgBB}$ dalam 1 jam pertama (). Prediksi total permintaan darah akan meningkat $0,81 \%$ pertahun dari 13.459 unit pada tahun 2009 menjadi 15.183 unit pada tahun 2014. Kasus thalasemia baru membutuhkan 31,7\% dari seluruh permintaan darah pada tahun 2024. Kebutuhan darah me- ngalami peningkatan stabil sampai 10 tahun ke depan. Penelitian Guerin, et al., menemukan variabel yang berpengaruh pada kebutuhan darah secara bivariat adalah kadar $\mathrm{Hb}$, berat badan, dan usia (7).

\section{KESIMPULAN}

Berdasarkan hasil penelitian dan pembahasan, didapatkan kesimpulan dari hasil penelitian ini sebagai berikut:

1. Karakteristik pasien thalasemia mayor sebagian besar berjenis kelamin laki-laki, rata-rata usia 9,82 tahun $(\mathrm{SD} \pm 3,44)$, rata-rata berat badan adalah 23,64 $\mathrm{Kg}(\mathrm{SD} \pm$ $8,26)$, rata-rata kadar hemoglobin adalah $6,15 \mathrm{mg} / \mathrm{dL}(\mathrm{SD} \pm 1,32)$ dan rata-rata kebutuhan darah adalah 299,5 $\mathrm{ml}(\mathrm{SD} \pm 98)$ 


\section{Referensi}

1. Atmakusma D, Iswari S. Dasar-dasar talasemia: Salah satu jenis Hemoglobinopati. 5th ed. AW S, Setiyohadi B, Alwi I, Simadibrata M, Setiati S, editors. Jakarta: Pusat Penerbitan Departemen Ilmu Penyakit Dalam Fakultas Kedokteran Universitas Indonesia; 2010. 1379 p.

2. Data Statistik RHS. Data Morbiditas tahun 2002-2006. In.

3. Pignatti-Borgna C, Galanello R. Thalassemias and related disorder: Quantitative disorder of hemoglobin syntesis. Wintrobe's Clin Hematol. 2014;826-913.

4. Dirjen Bina Pelayanan Medik Kementrian Kesehatan Republik Indonesia. Health Technology Assessment Indonesia: Pencegahan Thalassemia. In 2010.

5. Rudolph AM, Hoffmand JIE, Rudolph CD. Buku ajar pediatri. Samik W, Sugiarto, editors. Jakarta: EGC; 2007.

6. Anggororini D, Fadlyana E, Idjradinata P. Korelasi kadar feritin serum dengan kematangan seksual pada anak penyandang thalassemia mayor. 2009;

7. Rejeki D, Nurhayati N, Supriyanto, Kartikasari P. Studi epidemiologi deskriptif talasemia. J Kesehat Masy Nas. 2012;7(3):139.

8. Zaki, Nur Zuriana, 2012. Karakteristik Pasien Thalassemia Rawat Inap di RSUP H Adam Malik Medan dari Tahun 2009 sampai 2010. Diunduh dari http://repository.usu.ac.id/handle/123456789/31252

9. Dewi S, 2009. Karakteristik Thalasemia Yang Di Rawat Inap Di Rumah Sakit Umum Pusat H. Adam Malik Medan.jurnal Skripsi. USU Repository, Hal:10-12.

10. Muhaj, K.2009. Askep Anak Thalassemia. Diakses dari http://www.medicastore.compada 7 Maret 2014.

11. Bulan, S. Faktor-faktor yang berhubungan dengan kulaitas hidup anak talasemia beta mayor, Semarang. Magister Ilmu Biomedik dan Program Pendidikan Dokter Spesialis IlmuKesehatan Anak, Universitas Diponegoro; 2009.

12. M a m b o . 20004 . Warisan yang Tidak Diharapkan. Diakses dari http://www.dkkbpp.com-sysinfokeskotabalikpapan/pada 3 Maret 2014

13. Thalasemia.org. Thalasemia Beta. Diakses pada 25 Oktober 2014 dari http:// thalasemia org /

14. Galebbo R, Raffael G, Beta Talasemia, Orphanet Journal Of Rare Disease, 2010; 5; 11. 